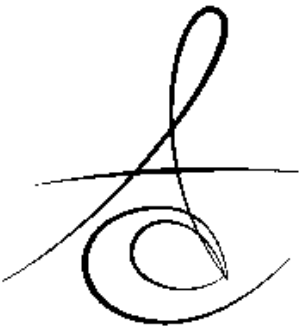

\section{PERIODONTAL HASTALIK GEÇMİşi OLAN VE PERIODONTAL OLARAK SAĞLIKLI BİREYLERDE YAPILAN İMPLANTLARIN 29 AYLIK GERİYE DÖNÜK KLİNİK BAŞARILARININ DEĞERLENDİRİLMESİ}

\section{THE SUCCESS RATES OF IMPLANTS IN PERIODONTALLY COMPROMISED AND PERIODONTALLY HEALTHY PATIENTS- A 29 MONTHS RETROSPECTIVE EVALUATION}

\author{
Dr. Dt. Işıl Damla ŞENER YAMANER*
}

Makale Kodu/Article code: 3862

Makale Gönderilme tarihi: 24.10.2018

Kabul Tarihi: 14.02.2019

\section{öz}

Amaç: $\mathrm{Bu}$ çalışmanın amacı periodontal hastalık geçmişine sahip bireylerde ve periodontal olarak sağlıklı bireylerde ortalama 29 aylık takip süresinde implant başarısının tespiti ve implant çevresi marjinal kemik kaybının hastaya bağlı parametreler olan diyabetes mellitus, sigara kullanımı, yaş ve cinsiyete göre karşılaştırılmasıdır.

Gereç ve Yöntem: Periodontal olarak sağlıklı (PSB) 14 birey ile periodontal hastalık geçmişi olan (PHB) 12 bireye toplamda 139 implant yerleştirildi. İmplantların final restorasyonları, 8-10 haftalık iyileşme sonrasında yüklendi. İmplantların çevresinde marjinal kemik kayıpları başlangıç ve ortalama 29 ay sonrasında radyografik olarak belirlendi. Diyabetes mellitus, sigara kullanımı, yaş ve cinsiyet faktörlerinin marjinal kemik kaybına olan etkisi incelendi.

Bulgular: Sigara kullanımı ve diyabetes mellitus, implant çevresi marjinal kemik kaybını PHB ve PSB gruplarında istatistiksel olarak anlamlı şekilde etkilemiştir $(p \leq 0,05)$. PHB grubunda kadın hastalarda marjinal kemik kaybı değerleri erkek hastalara kıyasla daha düşüktür. Buna karşılık PSB grubunda kadın hastalarda takip süresi içerisindeki ortalama kemik kaybı erkek hastalardan daha fazladır. Ancak her iki gruptaki bu farklılık istatistiksel olarak anlamlı bulunmamıştır $(p \geq 0,05)$. Takip süresi içerisindeki ortalama kemik kaybı değerleri her iki grup içinde genç bireylerde, orta ve yaşlı bireylere göre daha az bulunmuştur. Ancak bu farklılık istatistiksel olarak anlamlılık ifade etmemiştir $(p \geq 0,05)$. Çalışmada 29 aylık ortalama başarı oranı tüm implantlarda, PHB ve PSB gruplarında sırasıyla; $\% 95, \% 93,8$ ve $\% 96,6$ olarak tespit edilmiştir.

Sonuç: İmplantların takip süresi içerisindeki marjinal kemik kayıplarına diyabetes mellitus ve sigara kullanımının etkisi açıktır. Çevre marjinal kemik kayıpları periodontal hastalık geçmişi olan bireylerde, periodontal olarak sağlıklı bireylere göre istatistiksel olarak anlamlı artış göstermiştir. Bu açıdan periodontal hastalık geçmişi olan bireylerde implant tedavisinde ikincil başarısızlık faktörlerinin dikkatli değerlendirilmesi gerekmektedir.

Anahtar Kelimeler: Periodontitis, Dental İmplant, Diyabetes mellitus, İmplant Başarısı

\section{ABSTRACT}

Aim: The aim of this study is the evaluation of the success rate of implants in periodontally compromised and periodontally healthy patients in average 29 months follow-up time. And comparison of the marginal bone loss around implants according to patient related parameters as smoking, age, gender and diabetes mellitus.

Materials and Methods: 139 implants were placed in 14 periodontally healthy and 12 periodontally compromised patients and loaded with final restorations 8-10 weeks of healing time. Marginal bone loss around implants was determined radiographically at initial and after a mean observation time average of 29 months. Marginal bone loss around the implants was evaluated according to the patient's age and gender, smoking habit and presence of diabetes mellitus.

Results: The overall cumulative survival rate for 29 months was \% 95 and for PHB and PSB groups consecutively, \%93,8, \%96,6. Marginal bone loss was affected statistically significantly by smoking and diabetes mellitus, in both groups $(p \leq 0,05)$. Marginal bone loss around the implants in PHB group was higher than that of in PSB group.

Conclusion: The affect of smoking and diabetes mellitus is obvious for the marginal bone loss for both of the groups. And for periodontally compromised patients bone loss increases statistically significantly higher in comparison to healthy patients. During the implant treatment, for periodontally compromised patients secondary factors must be followed carefully.

Key words: Periodontitis, Dental Implant, Diabetes Mellitus, Survival Rate

\footnotetext{
* DMR DENT Ağız ve Diş Sağlığı Polikliniği, İstanbul.
} 


\section{GİRİŞ}

Günümüzde dişsiz boşlukların implantlar ve implant destekli restorasyonlarla tedavisi bilimsel olarak kabul görmüş rutin tedavi yöntemidir. Ancak bu yöntemle tedavi edilen periodontal hastalık hikâyesine sahip bireyler, uzun dönemde periimplantitis vb. biolojik komplikasyonlar ve implant kayıpları açısından yüksek risk grubu oluşturmaktadırlar. ${ }^{1,2}$

Karoussis ve $a$ ark. $^{3}$ periodontal olarak sağlıklı bireyler ile periodontal hastalık geçmişi olan bireyleri implant başarısı açısından karşılaştırdıkları prospektif çalışmalarında ilk 7 yılda belirgin olmamakla beraber sonraki 3 yılda periodontal hastalık geçmişi olan bireylerde, belirgin olarak yüksek implant kaybı tespit etmişlerdir. Ayrıca çok sayıda çalışmada periodontal hastalık geçmişi olan bireylerde, periimplant kemik kaybının sağlıklı bireylere oranla çok daha fazla olduğu sonucuna varılmıştır. ${ }^{4-6}$

Periodontal tedavi ile sondalama derinliği ve mobilite gibi lokal prognoz faktörleri giderilebildiğinden bunlar kontrol edilebilir faktörler olarak kabul edilebilir ancak sigara kullanımı ve diyabetes mellitus gibi hastaya bağlı faktörler kontrol edilemez faktörlerdir. ${ }^{7}$

Günümüzde gelişmekte olan ülkelerde yetişkinler arasında diyabetes mellitus, hızla artış gösteren sistemik bir hastalıktır. ${ }^{8}$ Dünya Sağlık Örgütü (WHO) tarafından yakın zamanda bildirilen veriler ışığında 7 milyon yetişkinin Tip 2 diyabetes mellitus, 3 milyon yetişkinin ise prediabetik olduğu bilinmektedir. Diyabetes mellitus hastaları; periodontal hastalık ve diş kaybı açısından yüksek risk taşıyan hastalardır. ${ }^{9}$

Liu ve ark. ${ }^{10}$ ve Tsai ve ark. ${ }^{11}$ çalışmalarında diyabetes mellitus hastalarında belirgin ataşman kaybı, persiste enflamasyon ve artmış alveolar kemik kaybı görüldüğünü belirtmişlerdir. Bu hastalarda periodontal hastalık varlığında, kemik kaybı ile onarıcı kemik oluşumunun azalışı birlikte görüldüğünden kemik kaybı artışının artarak devam ettiği tespit edilmiştir. ${ }^{10}$

Diyabetes mellitus hastalarında implant tedavisi uygulanabilir ancak kronik hiperglisemi, osteoblastların sentezini etkilemekte ve osteoklastların fonksiyonunu arttırmaktadır. Ayrıca kalsiyum ve potasyum metabolizmasını değiştirmektedir. Bu etkiler iyileşme fazında kemik formasyonunu azaltarak osteointegrasyon döneminde implant kayıplarına neden olabilmektedir. 12-15

Sigara kullanan bireylerde; diyabetes mellitus, gastro-özofagal reflü ve enflamatuar bağırsak hasta-
Iıkları gibi gastrointestinal hastalıkların ve oral hastalıklara yatkınlığın tespit edildiği yapılan çalışmalarda kanıtlanmıştır. ${ }^{16,17}$ Ayrıca sigara kullanımı oral mukoza lezyonları ve/veya kanserleri, ve periodontal hastalıklar için kuvvetli bir risk faktörüdür. ${ }^{18}$ Sigara kullanımı, fibroblast aktivitesi, antikor üretimi, nötrofil fonksiyonu ve enflamatuar mediyator üretimi gibi immün cevap aktivitelerine zarar verir. Sigara içen bireylerde içmeyen bireylere göre daha derin periodontal cepler, daha fazla alveoler kemik yıkımı ve daha fazla diş kaybı olduğu bildirilmiştir. ${ }^{19,20}$

Tedavi edilmemiş periodontal hastalık, sigara kullanımı ve kontrol altında olmayan diyabetes mellitus varlığında periodontal yıkımın ve diş kayıplarının oluşacağı çok sayıda çalışmada tespit edilmiştir. ${ }^{21}$ Kaybedilmiş eksik dişlerin bulunduğu bölgelerin implant uygulanarak restore edilmesi yaygınlıkla kullanılan bir tedavi yöntemidir. Periodontal hastalığa sahip bireylerde implant tedavisinin prognozu hakkında farklı bulgulara sahip çok sayıda çalışma mevcuttur. ${ }^{22,23}$

Bazı çalışmalar implant kayıpları ile periodontal hastalığı ilişkilendirmemiş ve aralarında bir ilişki olmadığı sonucuna varmışlardır. ${ }^{24,25}$ Farklı araştırmacılar tarafından yapılmış çalışmalarda ise periodontal hastalığa sahip bireylerin implant kaybı açısından yüksek risk grubu oluşturdukları bildirilmiştir. 3,26-28

$\mathrm{Bu}$ çalışmanın amacı periodontal hastalık geçmişi olan bireyler ile periodontal olarak sağlıklı bireylerde ortalama 29 aylık takip süresinde implant başarısının tespiti ve implant çevre kemik doku kaybının; sigara kullanımı, yaş, cinsiyet ve diyabetes mellitus gibi hastaya bağlı parametrelere göre karşılaştırılmasıdır.

\section{MATERYAL VE METOD}

Bu çalışmada kliniğimizde (DMR DENT Ağız ve Diş Sağlığı Polikliniği, Levent, İstanbul) 2014-2017 yılları arasında periodontal tedavisi tamamlanmış hastalar ile periodontal olarak sağlıklı bireylerden oluşan, yaşları 23 ila 80 arası değişen 19 erkek, 7 kadın olmak üzere toplam 26 hastada yapılan 139 dental implantın klinik başarısı ve kemik kayıpları değerlendirildi.

Çalışmada gruplar arasında karşılaştırma yapılabilmesi amacı ile gerekli implant sayısı belirlemek için istatistiksel olarak güç analizi yapıldı. Bu amaçla daha önceki benzer bir çalışmadan ${ }^{29}$ alınan ortalama 
ve standart sapma değerleri ile etki büyüklüğü tespit edilerek çalışmamızdaki gruplar için minimum örnek sayısı 57 olarak belirlendi.

14 hasta periodontal olarak sağlıklı bireyler (PSB) grubunu oluştururken, periodontal tedavi öncesinde ağız içerisinde var olan sondalanabilir ceplerin \%30 undan fazlasının sondalanabilir cep derinlikleri $\geq 4 \mathrm{~mm}$ olduğundan generalize kronik periodontitis teşhisi konan ve sonrasında periodontal tedavileri tamamlanan 12 hasta, periodontal hastalık geçmişi olan hastalar (PHB) grubunu oluşturdu. ${ }^{30}$

Hastaların medikal hikayeleri alındı. İmplant cerrahisi sırasında kontrol altında olan diyabetes mellitus hastaları ve osteoporoz gibi sistemik hastalıklara sahip bireyler çalışmaya dahil edildi. Sigara kullanımı ve bruksizm kayıt edildi ancak tedavi için kontraendikasyon olarak belirlenmedi. Hastalar sigara ve diyabetes mellitus hastalığının implant başarısı için risk olduğu konusunda bilgilendirildi.

Çalışmaya dahil edilen hastalar; implant yerleştirilmesi için yeterli kemik miktarı olması, greftleme intiyacı olmamasına ve implant bölgelerinin diş çekimini takiben $\geq 4$ aylık bir iyileşme sürecini tamamlamış olması kriterlerine göre belirlendiler.

İmplant cerrahisi lokal anestezi altında tek aşamalı cerahi protokole uygun olarak gerçekleştirilen hastalara transmukozal iyileşme için iyileşme kapakları yerleştirildi. Hastalara cerrahiden 1 saat önce başlamak üzere 5 gün boyunca $500 \mathrm{mg}$ amoksisilin antibiyotik ve dikiş alınana kadar günde 2 kez $0.1 \%$ klorheksidin gargara reçete edildi. Operasyon sonrası 7-10 gün içerisinde dikişler alınarak operasyon bölgesi klinik olarak kontrol edildi. Hiçbir hasta iyileşme sürecinde geçici restorasyon kullanmadı. Tüm implantlar, 8-10 haftalık iyileşme sürecini takiben yüklendiler. Tüm hastalar sabit protetik restorasyonla tedavi edildiler. İyileşme süreci sonrasında protetik tedavi prosedürü; polieter ölçü materyali ile kapalı kaşık tekniği kullanılarak ölçü alımı sonrasında metal destekli porselen restorasyonların simantasyonu şeklinde tamamlandı.

İmplantların distal ve mesial kenarlarındaki kemik seviyelerinin değişimlerinin hesaplanabilmesi amacıyla ilk olarak implant yerleştirilmesinin hemen sonrasında ve yükleme sonrası ortalama 29 ay sonra standardize edilmiş dijital panoramik radyograflar (Orthophos XG; Sirona Dental Systems, Bensteim, Germany) elde edildi. Marjinal kemik kaybının tespiti amacıyla tek bir araştırmacı tarafından implant boynundan kemik ile implantın ilk temas noktası arasındaki mesafe ölçüldü. Radyografilerin distorsiyonu ve anatomik büyütmesinin kalibrasyonu, implantların klinik verileri olan çap ve boy değerleri ve iki yiv arası mesafeleri ile yapıldı. Radyografik görüntü boyutlarının kalibrasyonu için basit matematiksel hesaplama yapıldı. ${ }^{31}$

PHB ve PSB olmak üzere iki grup arasındaki marjinal kemik kaybı; yaş, cinsiyet, sigara kullanımı ve diyabetes mellitus parametrelerine göre karşılaştırıldı.

İmplant başarısı Buser ve ark. ${ }^{32}$ nın çalışmasında tanımladığı implant başarı kriterleri ile tespit edildi. Bu başarı kriterleri; 1-Devamlı ağrı, yabancı cisim hissi ve/veya disestezi; 2-Süpürasyonla birlikte tekrarlayan periimplant enfeksiyonu; 3-İmplant mobilitesi; ve 4-İmplant çevresinde devamlılık gösteren radyolusent alan varlığı, olarak belirlendi.

İstatistiksel analizler SPSS istatistik programında (IBM SPSS Inc., Chicago, IL) hazırlandı. İmplantların uzun dönem klinik başarılarını değerlendirmede Kaplan-Meier algoritması kullanıldı. Her iki grubun ortalama marjinal kemik kaybı değerleri, standart deviasyonları ve parametrelere göre gruplar arası ve grup içi karşılaştırmaları tek yönlü ANOVA testi ile değerlendirildi. Tüm test grupları arasında istatistiksel olarak farklılık $\mathrm{p} \leq 0,05$ anlamlılık değeri ile ölçüldü.

\section{BULGULAR}

Bu çalışmada yaşları 23 ila 80 arasında değişen 26 hastaya toplamda 139 adet implant yerleştirildi. Çalışmaya katılan erkek hastaların yaş ortalaması 56,6 (yaş aralığı 35-80) iken, kadın hastaların yaş ortalaması 56,7 (yaş aralığı 23-71) olarak belirlendi.

Çalışmadaki hastaların \% 53,8' i periodontal olarak sağlıklı bireylerden oluşurken, \% 46,2' si periodontal hastalık geçmişi olan hastalardı. Periodontal olarak sağlıklı bireylerin \% 28,6' sını kadınlar, \% 71,4' ünü erkekler oluştururken, periodontal hastalık geçmişi olan hastaların, \%25' ini kadınlar, \%75' ini erkekler oluşturmaktaydı.

Hastaların \% 61,6 SI sigara kullanmazken, $\% 11,5^{\prime}$ i kadın, \% 26,9'u erkek olmak üzere toplamda $\% 38,4$ 'ü sigara kullanan bireylerdi. Hastaların sistemik durumları incelendiğinde ise \%34,6 'sının kontrol altına alınmış diyabetes mellitus hastası olduğu belirlendi (Tablo 1 ). 
Tablo 1. Hastaların sigara kullanımı, diyabetes mellitus, cinsiyet ve yaş kriterlerine göre dağılımı.

\begin{tabular}{|l|c|c|c|c|}
\hline \multirow{2}{*}{ Klinik Parametreler } & \multicolumn{2}{|c|}{ PSB } & \multicolumn{2}{c|}{ PHB } \\
\cline { 2 - 5 } & Kadın & Erkek & Kadın & Erkek \\
\hline Sigara Kullanımı & 1 & 2 & 2 & 5 \\
\hline Diyabetes mellitus & 1 & 0 & 1 & 7 \\
\hline Cinsiyet & 4 & 10 & 3 & 9 \\
\hline Yaş & \multicolumn{4}{|l}{} \\
\hline $0-40$ & 1 & 3 & 0 & 0 \\
\hline $40-60$ & 1 & 4 & 0 & 5 \\
\hline 60 üstü & 2 & 3 & 3 & 4 \\
\hline
\end{tabular}

Diş kayıplarının sebepleri incelendiğinde; 11 hastanın periodontal sebeplerle dişlerini kaybettiği, 15 hastanın ise travma ve/veya çürük sebebiyle dişlerini kaybettiği tespit edildi.

Toplamda 139 adet implantın 53 tanesinin $(\% 38,1)$ üst çeneye, 86 tanesinin ise $(\% 61,9)$ alt çeneye yerleştirildiği belirlendi. PHB grubundaki hastalara 67 adet implant yerleştirilirken PSB grubunda yerleştirilen implantların sayısı 72 dir. İmplantların ağız içerisindeki bölgelere göre dağılımı incelendiğinde ise; yalnızca hastaların \%19,2 sinde üst çenede anterior bölgede implant mevcutken, alt çene anterior bölgede hiç implant tespit edilmedi. Hastaların \%80,8 inde implantlar alt ve/veya üst çenede küçük azı ve/veya büyük azı bölgelerine yerleştirilmişlerdi.

İmplant destekli restorasyonların, karşıt dentisyonunun 66 adedi doğal diş ve 73 adedi ise implant destekli restorasyonlardan oluşmaktaydı.

Yerleştirilen implantların boyları 6-13 mm arasında değişirken, çapları da 3,3-5,0 mm arasındaydı. Yapılan implantların 71 adedi $<4 \mathrm{~mm}$ iken, 68 adedi . $\geq 4$ mm.di.

İmplantların tamamında osseointegrasyon olmasına rağmen hepsi erkek hastalarda olmak üzere; 4 tanesi, periodontal hastalık geçmişi olan ve diyabetes mellitus hastalarında ki bu hastalardan biri aynı zamanda sigara kullanmakta, 1 tanesi periodontal hastalık geçmişi olan ve sigara kullanan hastada ve 2 tanesi sistemik ve periodontal olarak sağlıklı, sigara kullanmayan hastada olmak üzere toplamda 7 implant sırasıyla 20, 21, 27, 36, 40, 34 ve 6.aylarda kaybedildi.

Tüm implantlar mobilite ve periimplantitis sebebiyle çıkartıldılar. Tüm implantlardaki ortalan-ma 29 aylık takip süresi içerisndeki başarı oranı \%95 tir (Tablo 2). Buna karşılık periodontal olarak sağlıklı ve periodontal hastalık geçmişi olan bireylerdeki başarı oranı sırasıyla \% 96,6 ve \% 93,8 olarak hesaplanmıştır (Tablo 3 ).

Tablo 2. Tüm implantların başarı oranı.

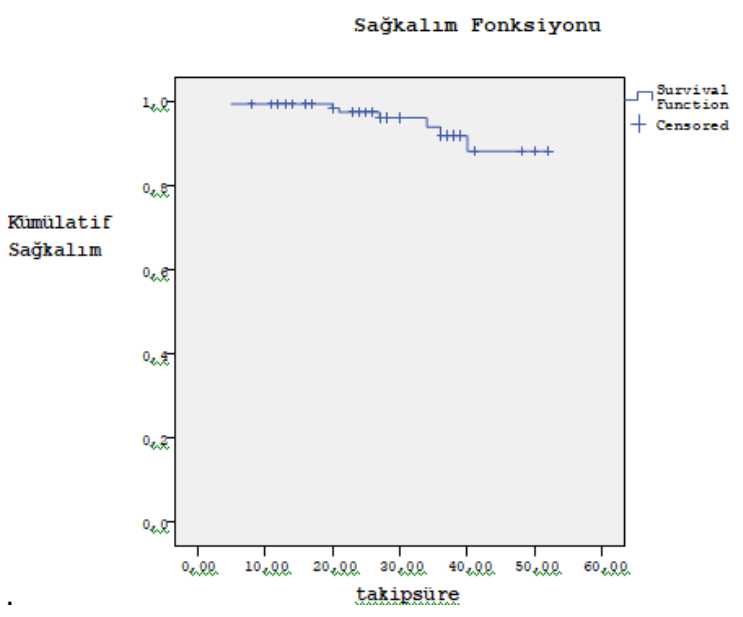

Tablo 3. PSB ve PHB gruplarında implantların başarı oranları.
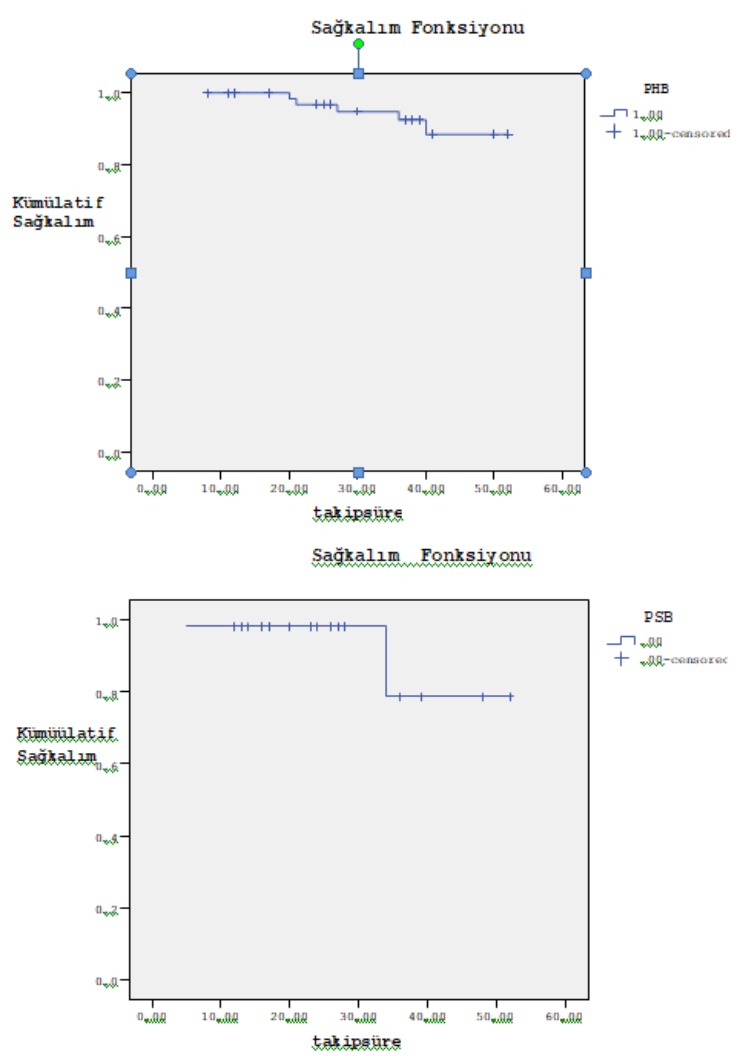
Takip süresince periodontal hastalık geçmişi olan hastalardaki ortalama kemik kayıpları $(2,15 \pm 1,43$ $\mathrm{mm}$ ) periodontal olarak sağlıklı bireylerdeki ortalama kemik kayıplarına göre $(0,40 \pm 0,14 \mathrm{~mm})$ istatistiksel olarak anlamlı derecede daha yüksek bulunmuştur $(p \leq 0,05)$. (Resim 1)

Ortalama kemik kaybi; sigara kullanan hastalarda, PHB grubunda 3,29 $\pm 0,54 \mathrm{~mm}$ iken PSB grubunda $0,61 \pm 0,86 \mathrm{~mm}$, sigara kullanmayan hastalarda PHB grubunda 0,95 $\pm 0,11 \mathrm{~mm}$ iken PSB grubunda $0,32 \pm 0,10 \mathrm{~mm}$ olarak bulunmuştur.

Diyabetes mellitus hastalarında, PHB grubunda

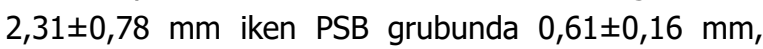
sistemik olaralk sağlıklı hastalarda, PHB grubunda $1,21 \pm 0,72 \mathrm{~mm}$ iken PSB grubunda 0,39 $\pm 0,82 \mathrm{~mm}$ olarak bulunmuştur (Tablo 4).

Tablo 4. PSB ve PHB gruplarında marjinal kemik kaybı değerleri ve karşılaştırmalı istatiksel analizi

\begin{tabular}{|c|c|c|c|c|c|c|}
\hline \multirow{2}{*}{\multicolumn{2}{|c|}{$\begin{array}{c}\text { Klinik } \\
\text { Parametreler }\end{array}$}} & \multicolumn{2}{|c|}{$\begin{array}{c}\text { Ortalama ve Std. } \\
\text { sapma }\end{array}$} & \multirow{2}{*}{$\begin{array}{c}P \\
\text { değer } \\
\mathrm{i}\end{array}$} & \multirow[t]{2}{*}{ Toplam } & \multirow{2}{*}{$\begin{array}{c}P \\
\text { değe } \\
\text { ri }\end{array}$} \\
\hline & & PHB & PSB & & & \\
\hline \multirow[t]{2}{*}{$\begin{array}{c}\text { Sigara } \\
\text { kullanımı }\end{array}$} & $\begin{array}{c}\text { Sigara } \\
+\end{array}$ & $3,29 \pm 0,54$ & $0,61 \pm 0,86$ & $0,000 *$ & $2,49 \pm 1,54$ & \multirow[t]{2}{*}{$0,000 *$} \\
\hline & sigara - & $0,95 \pm 0,11$ & $0,32 \pm 0,10$ & $0,000 *$ & $0,69 \pm 0,30$ & \\
\hline \multirow{2}{*}{$\begin{array}{c}\text { Diyabetes } \\
\text { mellitus }\end{array}$} & DM+ & $2,31 \pm 0,78$ & $0,61 \pm 0,16$ & $0,000^{*}$ & $2,03 \pm 1,65$ & \multirow[t]{2}{*}{$0,000 *$} \\
\hline & DM - & $1,21 \pm 0,72$ & $0,39 \pm 0,82$ & $0,000^{*}$ & $0,91 \pm 0,87$ & \\
\hline \multirow[t]{2}{*}{ Cinsiyet } & Kadın & $1,67 \pm 0,45$ & $0,43 \pm 0,12$ & 0,963 & $1,55 \pm 0,68$ & \multirow[t]{2}{*}{0,111} \\
\hline & Erkek & $2,53 \pm 0,65$ & $0,39 \pm 0,11$ & 0,752 & $1,90 \pm 0,74$ & \\
\hline \multirow[t]{3}{*}{ Yaş } & Genç & $1,88 \pm 0,54$ & $0,31 \pm 0,18$ & 0,653 & $1,77 \pm 0,11$ & \multirow[t]{3}{*}{1,152} \\
\hline & Orta & $2,56 \pm 0,63$ & $0,43 \pm 0,12$ & 0,544 & $1,55 \pm 1,40$ & \\
\hline & Yaşlı & $2,08 \pm 0,93$ & $0,46 \pm 0,10$ & 0,591 & $1,40 \pm 1,41$ & \\
\hline Toplam & & $2,15 \pm 1,43$ & $0,40 \pm 0,14$ & $0,000^{*}$ & & \\
\hline
\end{tabular}

* anlamlılık seviyesi $(\mathrm{p} \leq 0.05)$

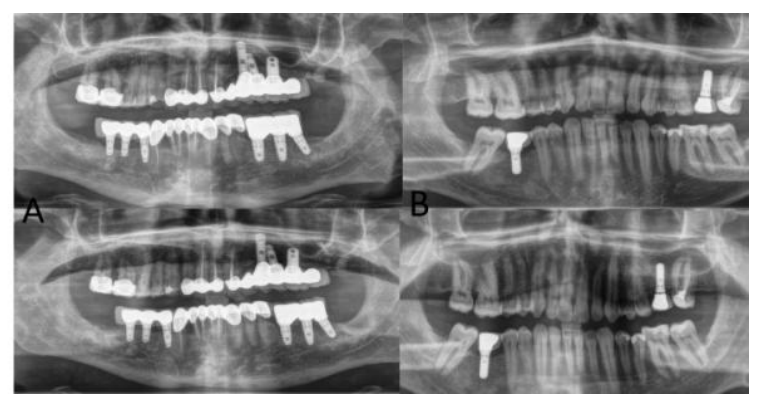

Resim 1. A) Periodontal hastalık geçmişi olan hastada 44,45,46 nolu implantlardaki marjinal kemik kaybı B) Periodontal olarak sağlıklı hastada 45 no lu implant bölgesindeki marjinal kemik kaybı

Diyabetes mellitus hastalarında takip süresi içerindeki ortalama kemik kaybı her iki takip grubunda da (PSB, PHB) sağıklı bireylere göre daha fazla bulunmuştur. Bu farklıık istatistiksel olarak anlamlıdır $(p \leq 0,05)$.
Sigara kullanımı ve diyabetes mellitus, implant çevresi marginal kemik kaybını her iki grupta istatistiksel olarak anlamlı şekilde etkilemiştir ( $p \leq$ 0,05).

Periodontal hastalık geçmişi olan kadın hastalarda marjinal kemik kaybı değerleri erkek hastalara kıyasla daha düşüktür. Buna karşlık periodontal olarak sağlıkı kadın hastalarda takip süresi içerisindeki ortalama kemik kaybı erkek hastalardan daha fazladır. Ancak her iki gruptaki bu farklılık istatistiksel olarak anlamlı bulunmamıştır $(p \geq 0,05)$.

Takip süresi içerisindeki ortalama kemik kaybı değerleri her iki grup içinde genç bireylerde orta ve yaşlı bireylere göre daha az bulunmuştur. Ancak bu farklllık istatistiksel olarak anlamlılık ifade etmemiştir $(p \geq 0,05)$.

\section{TARTIŞMA}

Uzun dönem klinik takipler implant tedavisinin başarııının değerlendirilmesinde önemli rol oynar. Ancak implant çevresi marjinal kemik kayıplarının yüksek oranda implant yerleştirilmesini takip eden ilk bir yıl içerisinde görüldüğü tespit edilmiştir. Çalışmamızda implantların klinik takip süresi ortalama 29 aydır. Bu kısa süreli klinik takip süresi implantların en fazla kemik kaybına uğradığı dönemi kapsamaktadır. Bu açıdan çalışmamızın amacı ilk yıl içerisinde görülen agresif kemik kaybına, geçmiş periodontal hastalık hikayesinin etkisini incelemektir.

Marjinal kemik kaybının değerlendirilmesinde genellikle radyografik yöntemler kullanılmaktadır. Bu yöntemler içerisinde en sıklıkla kullanılan yöntem paralel teknikle çekilen periapikal radyografilerdir. Detaylı bilgi vermesi sebebiyle çalışmalarda sıklıkla periapikal radyografiler kullanımasına rağmen çok sayıda çalışmada panoramik radyografilerin implant çevresi marjinal kemik kaybının değerlendirilmesinde kullanıldığı görülmektedir. Özellikle çok sayıda implantın bulunduğu vakalarda hasta konforu ve radyolojik doz açısından panaromik radyografiler kullanılmaktadır. ${ }^{33}$

$\mathrm{Bu}$ çalışmada da implantların marjinal kemik kaybının değerlendirilmesinde panoramik radyografiler kullanıımışır.

Çalışmamızda implant tedavisi görmüş hastalardaki marjinal kemik kayıpları ve implant başarısızlıkları değerlendirilirken hastanın periodontal geçmişi olup olmadığı asıl parametredir. Ancak implant

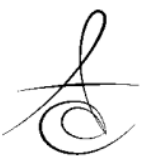


başarısızlığını ve marjinal kemik kaybını etkileyen sigara kullanımı, diyabetes mellitus, yaş ve cinsiyet gibi diğer önemli faktörlerinde her iki gruptaki marjinal kemik kayıplarına etkisi olabileceği düşünüldüğünden çalışmamızda ek parametreler olarak değerlendirilmiştir.

Son yıllarda, periodontal hastalık geçmişi olan bireylerin, periodontal olarak sağlıklı bireylere göre daha yüksek periimplantitis riski taşıdığı bildirilmiştir. ${ }^{26-}$ ${ }^{28}$ Agresif ve kronik periodontitisli hastalarda implant kaybı riskinin daha yüksek olduğu ve bu riskin agresif periodontitisli bireylerde kronik periodontitisli bireylere göre daha fazla olduğu gösterilmiştir. ${ }^{34}$ Monje ve ark. ${ }^{34}$ yaygın agresif periodontitisli bireylerdeki implantların sağ kalım oranlarının kronik periodontitis ya da sağlıklı bireylerdekiler ile benzer olabilmesine rağmen, başarısızlık oranının yaygın agresif periodontitisli bireylerde gerek kronik periodontitis gerekse de sağlıklı bireylere göre daha fazla olduğunu göstermişlerdir.

Çalışmamızda implantların takip süresi içerisindeki başarısı Buser ve ark. ${ }^{32}$ ' nın değerlendirme kriterlerine göre değerlendirilmiştir. Bu kriterlere göre 29 aylık ortalama başarı oranı tüm implantlarda \%95 olarak tespit edilmiştir.

Periodontal geçmişi olan bireylerde klinik takip süresi 3 yıla yaklaşan çalışmalarda implantların başarı oranları \%91-98 arasında değişmektedir. Buna karşılık aynı çalışmalarda periodontal olarak sağlıklı bireylerde başarı oranları \%96-100 arası değişmektedir. ${ }^{5,35,36} \mathrm{Bu}$ çalışmada da benzer olarak Periodontal hastalık geçmişi olan ve periodontal olarak sağlıklı bireylerde bu oran sırasıyla \% 93,8 ve \% 96,6 olarak belirlenmiştir.

Klinik takip süresi 7-15 yıl arasında olan çalışmalarda periodontal olarak sağlıklı bireylerde başarı oranları 1-3 yıl arası kısa süreli takip çalışmalarındaki başarı düzeyinde kalırken, aynı çalışmalarda periodontal hastalık geçmişi olan hastalarda başarı oranı belirgin olarak düşerek \% 75-85 aralığına düşmektedir. 37-39

$\mathrm{Bu}$ durum periodontal geçmişin implantların uzun dönemdeki başarısını olumsuz etkilediğini düşündürmektedir. Çalışmamızdaki implantların klinik takip süresi erken dönem periodunu içerdiğinden başarı oranları yüksektir ancak her iki grubun arasındaki farklıı̆ın belirlenebilmesi için daha uzun klinik takip çalışmasına intiyaç vardır.

Hardt ve ark. ${ }^{29}$ periodontitisli ve PSB grubunda implant çevresi kemik kaybını karşılaştırdıkları çalış- malarında 5 yıl sonunda sırasıyla $2.2 \pm 0.8 \mathrm{~mm}, 1.7 \pm$ $0.8 \mathrm{~mm}$ kayıp tespit etmişlerdir. Gatti ve ark. ${ }^{40}$ çalışmalarında kronik periodontitisli bireylerde $2.72 \pm 0.44$ $\mathrm{mm}$, PSB grubunda ise $1.24 \pm 1.09 \mathrm{~mm}$ lik kemik kayıpları ölçmüşlerdir. Matarasso ve ark. ${ }^{22}$ iki farklı implant tipini değerlendirdikleri çalışmalarında periodontitisli ve PSB grubunda sırasıyla $2.78 \pm 0.48$ ve $2.32 \pm$ $0.41 \mathrm{~mm}$ ile $1.95 \pm 0.42$ ve $1.43 \pm 0.38 \mathrm{~mm}$ kemik kaybı belirtmişlerdir. Aglietta ve ark. ${ }^{39}$ da Matarosso ve ark. ${ }^{22}$ nın çalışma dizaynına benzer çalışmalarında periodontitisli ve PSB grubunda sırasıyla $3.47 \pm 1.09$ ve $3.77 \pm 1.43 \mathrm{~mm}$ ile $2.65 \pm 0.31$ ve $2.51 \pm 0.31 \mathrm{~mm}$. kemik kayıpları tespit etmişlerdir. Roccuzzo ve ark. ${ }^{41}$ ise periodontal hastalığı derecelendirerek inceledikleri çalışmalarında, agresif periodontitisli bireylerde $0.98 \pm 1.22 \mathrm{~mm}$, orta düzeyde periodontitisli bireylerde $1.14 \pm 1.11 \mathrm{~mm}$ ve PSB grubunda $0.75 \pm 0.88 \mathrm{~mm}$ lik kayıplar tespit etmişlerdir.

Bu sonuçlar uzun dönem takip sonuçları olduğundan dolayı çalışmamızdaki kayıp miktarlarından fazladır. Sağlıkı bireylerde ve diyabetes mellitus hastalarında kemik kaybını karşılaştıran bir takip çalışmasında ${ }^{42}$ ise 2 yıl sonunda diyabetes mellitus hastaları ve sistemik olarak sağlıklı bireylerde kemik kaybı sırasıyla 0,74 $\pm 0,62 \mathrm{~mm}, 0,33 \pm 0,46 \mathrm{~mm}$ olarak tespit edilmiş, bu çalışmada da periodontal olarak sağlıklı

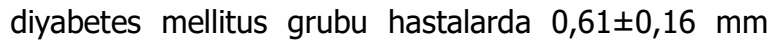
iken periodontal ve sistemik olarak sağlıklı hastalarda

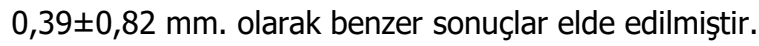

Aglietta ve ark. ${ }^{39}$ Periodontal açıdan sağlıklı sigara içen hastalarla, tedavi edilmiş periodontitis hikayesi olan sigara içen hastaları kıyasladıkları çalışmalarında daha düşük implant başarısı ve daha yüksek marjinal kemik kaybı tespit etmişlerdir.

Koldsland ve ark. ${ }^{43}$ nın yaptıkları çalışmalarında sigara kullanımı ve periodontal geçmişi olan bireylerin ortalama $8,4(1,1-16)$ yıl süre içerisinde implant kaybı yaşadıklarını kanıtlayan sonuçları diğer çalışmaların sonuçlarını destekleyici niteliktedir.

$\mathrm{Bu}$ çalışmada da sigara kullanan hastalarda marjinal kemik kaybı sigara içmeyen hastalara göre istatistiksel olarak anlamlı olarak yüksek bulunmuştur. Ayrıca sigara kullanan hastalarda periodontal geçmişin bulunması marjinal kemik kaybı değerlerini istatistiksel olarak anlamlı olarak arttırmıştır. Bunun anlamı periodontal geçmişi olan hastalarda var olan kemik kaybı riskinin sigara kullanımı ile uzun dönemde artabileceğidir. 
Nobre ve ark. ${ }^{44} 33$ kadın 37 erkek olmak üzere 70 diyabetes mellitus hastası üzerinde yaptıkları çalışmalarında 1 yıllık takip süreci sonrasında; tüm hastalar, tip 1 ve tip 2 DM hastalarında sırasıyla 0,88 $\mathrm{mm}, 1,64 \mathrm{~mm}$ ve 0,79 mm marjinal kemik kaybı tespit etmişlerdir. Aynı çalışmada 5 yıl sonunda ise 1,56 mm, 2,55 mm ve $1,45 \mathrm{~mm}$ lik kayıplar tespit edilmiştir.

Bu çalışmada da diyabetes mellitus hastalarında kemik kaybı tüm hasta gruplarında sağlıklı bireylere göre istatistiksel olarak anlamlı olarak daha yüksek bulunmuştur. Periodontal olarak sağlıklı olan, diyabetes mellitus hastalarında marjinal kemik kaybı değerleri benzer çalışmalardakilere eşdeğerdir. Ancak diyabetes mellitus hastalarında periodontal hastalık geçmişi bulunması implant çeveresi kemik kaybını arttırmıştır. Yakın zamanda yapılan derleme çalışmasında, ${ }^{45}$ diyabetes mellitus hastalarında periodontal hastalık geçmişi, marjinal kemik kaybını tetikleyici bir faktör olarak bildirilmiştir. Bu nedenle periodontal hastalık geçmişinin, diyabetes mellitus hastalarının implantlarında uzun dönemde başarısını olumsuz yönde etkileyen ikincil bir faktör olduğu düşünülmelidir.

Çalışmamızda implant çevresindeki marjinal kemik kaybına 29 aylık takip döneminde cinsiyet ve yaşın istatistiksel olarak anlamlı bir etkisi bulunamamıştır. Literatürde implantların uzun dönem takibi ile ilgili yapılan çalışmalarda yaş ve cinsiyetin marjinal kemik kaybına etkisi üzerine çelişkili raporlar bulunmaktadır. ${ }^{46} \mathrm{Bu}$ açıdan her iki parametreninde uzun dönem takiplerde değerlendirilmesi gerekmektedir.

\section{SONUÇ}

Çalışmamızda 29 aylık takip süresinde aşağıdaki sonuçlar elde edilmiştir.

1. Tüm implantlarda ki başarı oranı \%95 tir. Periodontal olarak sağlıklı ve Periodontal hastalık geçmişi olan bireylerde başarı oranları sırasıyla \% 96,6 ve $\% 93,8$ dir.

2. İmplantların takip süresi içerisindeki marjinal kemik kayıplarına diyabetes mellitus ve sigara kullanımının etkisi istatistiksel olarak anlamlıdır. Buna karşın cinsiyet ve yaşın anlamlı bir etkisi bulunamamıştır.

3. İmplantların takip süresi içerisindeki marjinal kemik kayıpları periodontal hastalık geçmişi olan bireylerde, periodontal olarak sağlıklı bireylere göre istatistiksel olarak anlamlı artış göstermiştir. Bu açıdan periodontal hastalık geçmişi olan bireylerde implant tedavisinde ikincil başarısızlık faktörlerinin dikkatli değerlendirilmesi gerekmektedir.

I. Damla Şener Yamaner: ORCID ID: 0000-0002-47906542

\section{KAYNAKLAR}

1.Ong CTT, Ivanovski S, Needleman IG, Retzepi M, Moles DR, Tonetti MS, Donos N. Systematic review of implant outcomes in treated periodontitis subjects. J Clin Periodontol 2008; 35: 438-62.

2.Renvert S,Persson GR. Periodontitis as a potential risk factor for peri-implantitis. J Clin Periodontol 2009; 36: 9-14.

3.Karoussis IK, Salvi GE, Heitz-Mayfield $\sqcup$, Bragger $U$, Hammerle $\mathrm{CH}$, Lang NP. Long-term implant prognosis in patientswith and without a history of chronic periodontitis: a 10 -year prospective cohort study of the ITI Dental Implant system. Clin Oral Implants Res 2003; 14: 329-39.

4.Mengel $R$, Behle $M$, Flores de Jacoby $L$. Osseointegrated implants in subjects treated for generalized aggressive periodontitis: 10-year results of a prospective, long-term cohort study. J Periodontol 2007; 78: 2229-37.

5.Mengel R, Flores-de-Jacoby L. Implants in patients treated for generalized aggressive and chronic periodontitis: a 3-year prospective longitudinal study. J Periodontol 2005; 76: 534- 43.

6.Aloufi F, Bissada N, Ficara A, Faddoul F, Al- Zahrani MS. Clinical assessment of periimplant tissues in patients with varying severity of chronic periodontitis. Clin Implant Dent Relat Res 2009; 11: 37-40.

7. Grossi SG, Genco RJ. Periodontal disease and diabetes mellitus: A two-way relationship. Ann Periodontol 1998; 3: 51-61.

8. Guariguata L, Whiting DR, Hambleton I, Beagley J, Linnenkamp $U$, Shaw JE. Global estimates of diabetes prevalence for 2013 and projections for 2035. Diabetes Res Clin Pract 2014; 103: 137-49.

9. Almas K, Al-Qahtani M, Al-Yami M, Khan N. The relationship between periodontal disease and blood glucose levelamong type II diabetic patients. J Contemp Dent Pract 2001; 2: 18-25.

10. Liu R, Bal HS, Desta T, Krothapalli N, Alyassi M, Luan $Q$ et al. Diabetes enhances periodontal bone

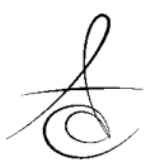


loss through enhanced resorption and diminished bone formation. J Dent Res 2006; 85: 510-4.

11. Tsai C, Hayes C, Taylor GW. Glycemic control of type 2 diabetes and severe periodontal disease in the US adult population. Community Dent Oral Epidemiol 2002; 30: 182-92.

12. Singhal S, Pradeep AR, Kanoriya D, Garg V. Human soluble receptor for advanced glycation end products and tumor necrosis factor-a as gingival crevicular fluid and serum markers of inflammation in chronic periodontitis and type 2 diabetes. J Oral Sci 2016; 58: 547-53.

13. Chang PC, Chien LY, Yeo JF, Wang YP, Chung MC, Chong LY et al. Progression of periodontal destruction and the roles of advanced glycation end products in experimental diabetes. J Periodontol 2013; 84: 379-88.

14. Abduljabbar T, Al-Sahaly F, Al-Kathami M, Afzal S, Vohra F. Comparison of periodontal and periimplant inflammatory parameters among patients with prediabetes, type 2 diabetes mellitus and non-diabetic controls. Acta Odontol Scand 2017; 75: 319-24.

15. Al Amri MD, Abduljabbar TS, Al-Kheraif AA, Romanos GE, Javed F. Comparison of clinical and radiographic status around dental implants placed in patients with and without prediabetes: 1-year follow-up outcomes. Clin Oral Implants Res 2017; 28: 231-5.

16. U.S. Department of Health and Human Services. The health consequences of smoking: a report of the Surgeon General. Atlanta, GA: U.S. Department of Health and Human Services. Office on Smoking and Health, 2004.

17. Mallampalli A, Guntupalli KK. Smoking and systemic disease. Clin Occup Environ Med 2006; 5: 173-92.

18. Winn DM. Tobacco use and oral disease. J Dent Educ 2001; 65: 306-12.

19. Axelsson P, Paulander J, Lindhe J. Relationship between smoking and dental status in 35-, 50-, 65-, and 75-year-old individuals. J Clin Periodontol 1998; 25: 297-305.

20. Van der Velden U, Varoufaki A, Hutter JW, Xu L, Timmerman MF, Van Winkelhoff AJ, Loos BG. Effect of smoking and periodontal treatment on the subgingival microflora. J Clin Periodontol 2003; 30: 603-10.
21. Genco RJ, Borgnakke WS: Risk factors for periodontal disease. Periodontol 2000 2013; 62: 59-94.

22. Matarasso S, Rasperini G, Iorio Siciliano V, Salvi GE, Lang NP, Aglietta M: A 10-year retrospective analysis of radiographic bone-level changes of implants supporting single-unit crowns in periodontally compromised vs. periodontally healthy patients. Clin Oral Implants Res 2010; 21 : 898-903.

23. Mengel $\mathrm{R}$, Schroder $\mathrm{T}$, Flores-de-Jacoby $\mathrm{L}$ : Osseointegrated implants in patients treated for generalized chronic periodontitis and generalized aggressive periodontitis: 3- and 5-year results of a prospective long-term study. J Periodontol 2001; 72: 977-89.

24. Klokkevold PR, Han TJ: How do smoking, diabetes, and periodontitis affect outcomes of implant treatment? Int J Oral Maxillofac Implants 2007; 22 Suppl:173-202.

25. Jiang BQ, Lan J, Huang HY, Liang J, Ma XN, Huo LD, Xu X: A clinical study on the effectiveness of implant supported dental restoration in patients with chronic periodontal diseases. Int J Oral Maxillofac Surg 2013; 42: 256-9.

26. Eick S, Ramseier CA, Rothenberger K, Brägger U, Buser D, Salvi GE. Microbiota at teeth and implants in partially edentulous patients. A 10-year retrospective study. Clin Oral Implants Res 2016; 27: 218-25.

27. Lee DW. Periodontitis and dental implant loss. Evid Based Dent 2014; 15: 59-60.

28. Ramanauskaite A, Baseviciene N, Wang $H L$, Tözüm TF. Effect of history of periodontitis on implant success: meta-analysis and systematic review. Implant Dent 2014; 23: 687-96.

29. Hardt CRE, Grondahl K, Lekholm U, Wennstrom JL. Outcome of implant therapy in relation to experienced loss of periodontal bone support -a retrospective 5-year study. Clini Oral Implants Res 2002; 13: 488-94.

30. Armitage GC. Development of a classification systems for periodontal diseases and conditions. Ann Periodontol 1999; 4: 1-6.

31. Galindo-Moreno P, Leon-Cano A, Monje A, et al. Abutment height influences the effect of platform switching on periimplant marginal bone loss. Clin Oral Implants Res 2016; 27: 167-73. 
32. Buser $D$, von Arx $T$, ten Bruggenkate $C$, et al. Basic surgical principles with ITI implants. Clin Oral Implants Res 2000; 11: 59-68.

33. Hopp M, de Araújo Nobre M, Maló P. Comparison of marginal bone loss and implant success between axial and tilted implants in maxillary Allon-4 treatment concept rehabilitations after 5 years of follow-up. Clin Implant Dent Relat Res 2017; 19: 849-59.

34. Monje A, Aranda $L$, Diaz KT, Alarcón MA, Bagramian $\mathrm{RA}$, Wang $\mathrm{HL}$, Catena $\mathrm{A}$. Impact of Maintenance Therapy for the Prevention of Periimplant Diseases: A Systematic Review and Metaanalysis. J Dent Res 2016; 95: 372-9.

35. Rosenquist B, Grenthe B. Immediate placement of implants into extraction sockets: implant survival. International J Oral Maxillofac Implants 1996; 11: 205-9.

36. Anner R, Grossmann Y, Anner Y, Levin L. Smoking, diabetes mellitus, periodontitis, and supportive periodontal treatment as factors associated with dental implant survival: a long-term retrospective evaluation of patients followed for up to 10 years. Implant Dent 2010; 19:57-64.

37. Fardal O, Linden GJ. Tooth loss and implant outcomes in patients refractory to treatment in a periodontal practice. J Clin Periodontol 2008; 35: 733-8.

38. Simonis $P$, Dufour $T$, Tenenbaum $H$. Long-term implant survival and success: a 10-16-year followup of nonsubmerged dental implants. Clin Oral Implants Res 2010; 21: 772-7.

39. Aglietta M, Siciliano VI, Rasperini G, Cafiero C, Lang NP, Salvi GE. A 10-year retrospective analysis of marginal bone-level changes around implants in periodontally healthy and periodontally compromised tobacco smokers. Clin Oral Implants Res 2011; 22: 47-53.

40. Gatti C, Gatti F, Chiapasco M, Esposito M. Outcome of dental implants in partially edentulous patients with and without a history of periodontitis: a 5-year interim analysis of a cohort study. European J Oral Implantol 2008; 1: 45-51.

41. Roccuzzo M, Bonino F, Aglietta M, Dalmasso P. Ten-year results of a three arms prospective cohort study on implants in periodontally compromised patients. Part 2: clinical results. Clin Oral Implants Res 2012; 23: 389-95.
42. Al Zahrani, Al Mutairi AA. Stability and bone loss around submerged and non-submerged implants in diabetic and non-diabetic patients: a 7-year followup. Braz Oral Res 2018;10:32:e57.

43. Koldsland OC, Scheie AA, Ass AM. Prevalence of implant loss and the influence of associated factors. J Periodontol 2009; 80: 1069-75.

44. de Araújo Nobre M, Maló P, Gonçalves $Y$, Sabas A, Salvado F. Dental implants in diabetic patients: retrospective cohort study reporting on implant survival and risk indicators for excessive marginal bone loss at 5 years. J Oral Rehabil 2016; 43:86370.

45. Chrcanovic BR, Albrektsson T, Wennerberg A. Diabetes and oral implant failure: a systematic review. J Dent Res 2014; 93: 859-67.

46. Hämmerle $C H F$, Cordaro $L$, Alccayhuaman KAA, Botticelli D, Esposito M, Colomina LE, Gil A, Gulje $\mathrm{FL}$, Ioannidis $A$, Meijer $\mathrm{H}$, Papageorgiou $\mathrm{S}$, Raghoebar G, Romeo E, Renouard F, Storelli S, Torsello F, Wachtel H. Biomechanical aspects: Summary and consensus statements of group 4 . The 5th EAO Consensus Conference 2018. Clin Oral Implants Res 2018; 29 Suppl 18: 326-31.

\author{
Yazışma Adresi \\ Dr. Dt. Işıl Damla ŞENER YAMANER \\ DMR DENT Ağız ve Diş Sağlığı Polikliniği \\ Levent Mah. Levent Cad. \\ Beşiktaş-İstanbul \\ Mail to; isildamlasener@gmail.com \\ Phone no: 02122703066 \\ Fax no: 02122703068
}

